\title{
シンポジゥム特集記事＼cjkstart総説
}

\author{
ヨーロッパ人類学会 \\ 佐 竹隆* \\ 日本大学松戸歯学部解剖人類形態学
}

(平成 19 年 12 月 20 日受付，平成 20 年 5 月 2 日受理)

\begin{abstract}
要 約
ヨーロッパ人類学会（EAA）は1976年に創設された。その目的は，互いに情報や意見の交換を行いヨー ロッパ諸国の人類学研究や人類学教育を推進していくことである。会員数は現在, 主にヨーロッパ諸国 30 r国以上からの 500 余名である。ニュース・レターが年 $2 \sim 3$ 回配布され，また，二年に一度書籍が出 版されている。学術大会は二年に一度ヨーロッパの各地で開催され，200 余名の参加がある。大学院生を 対象に人類学に関する講習会が 2007 年開催された。学会費は各国の経済状態により異なる。
\end{abstract}

キーワード：ヨーロッパ人類学会, 学術大会, ニュース・レター, 書籍, 講習会, 発育学

\section{The European Anthropological Association (EAA)}

\author{
Takashi Satake*
}

Nihon University School of Dentistry at Matsudo

(Received 20 December 2007; accepted 2 May 2008)

\begin{abstract}
The European Anthropological Association (EAA) was created in 1976. It is a scientific organization, which aims to promote research and teaching in anthropology in the different European countries and to promote exchanges of information, workshops, scientific congresses, and schools at the post graduate level. It attempts to bring together and generate synergy among people, institutions and organizations, which have shared interests in education in Anthropology. The EAA has more than 500 regular members from about 30 European and several non-European countries. A newsletter is distributed among all members two or three times a year. The EAA has also published a Biennial Book series since 1998. A congress of the EAA is arranged every two years in a different European host city. The first Intensive Course in Biological Anthropology Summer School was held at Charles University in Prague last summer. The EAA membership fee for regular member is not fixed; rather the fee has three levels based on the economic status of individual countries.
\end{abstract}

Key words: The European Anthropological Association (EAA), Congress of the EAA, Newsletter, Biennial Books of EAA, Seminor, Auxology

\footnotetext{
*日本大学松戸歯学部解剖人類形態学

干 271-8587 千葉県松戸市栄町西 2-870-1

E-mail: satake.takashi@nihon-u.ac.jp

(C2008 The Anthropological Society of Nippon
} 


\section{はじめに}

京都で必ず立ち寄る所がある。南禅寺の近くにある京 都市国際交流会館である。ヨーロッパ 詳しい碩学の コーナーがあるからである。しかし，筆者は人類学がヨー ロッパの長い歴史のなかでどのような位置を占めてきた のか，全くといっていいほど知識がない。ヨーロッパの 東西問題や多くの国から構成される欧州連合を考えるだ けでも，ヨーロッパ人類学会（The European Anthropological Association: EAA）には，何かにつけ国籍による微妙 な多くの問題がありそうなことは推察できる。

筆者はヨーロッパに住んだことも留学したこともな い。アメリカの Human Biology Association とイギリスの Society for the Study of Human Biology には所属している が, Human Biology Association や American Association of Physical Anthropologists $の$ Congress には一度, Society for the study of Human biology の Congress には参加したこと がない。そらいった経験で EAAを紹介する資格があるの か疑問ではあるが，Congress of the EAA に何度か参加し た経験から等身大の EAA の紹介を試みたい。したがって 不明確な箇所も多々あることが予想される。より客観的 な EAA の情報を得たい方は website（http://eaa.elite.hu/) を訪祆ていただき，小論と合わせて考兄ていただくとよ り具体的なイメージが得られるであろら。ともかく, EAA について何らかの情報が提供できれば幸いである。

\section{ヨーロッパ人類学会（EAA）の活動}

The European Anthropological Association（EAA）の設立 の目的は, ヨーロッパ諸国の人類学の研究や教育情報を 交換したり，支援したりすることである。具体的には， Newsletter (ニュース・レター) や Biennial Books of EAA (書籍) の発行（EAA の編集する雑誌は無いようである） とセミナー，学術大会の開催などが主なものである。規 模などは全く違うが，EAA はある意味でヨーロッパの AAPAのようなものであると考光る人もいるよらである。

\section{会員について}

会員の構成について Dr. Hauspie, R. (Free University of Brussels）に伺ったところ，2006 年度の会員数は表 1 飞 示すと打りである。40 以上もの多くの国からの会員で構 成されている。ロシアの 125 人を最高に, イタリア（59 人), クロアチア $(34$ 人), フランス, スペイン (33人), ドイッ（26人）の順で，学会員の総数は 514 名である。 学会費は各会員の国の経済状沉により変わるが，一般
Table 1 Number of the membership in the European Anthropological Association by country

\begin{tabular}{|c|c|}
\hline Country & Number of the membership \\
\hline ALBANIA & 2 \\
\hline AZERBAIJAN & 1 \\
\hline BELGIUM & 12 \\
\hline BULGARIA & 31 \\
\hline BYELARUS & 8 \\
\hline CANADA & 2 \\
\hline CHINA & 1 \\
\hline COLOMBIA & 1 \\
\hline CROATIA & 34 \\
\hline CZECH REPUBLIC & 4 \\
\hline DENMARK & 8 \\
\hline ESTONIA & 6 \\
\hline FRANCE & 33 \\
\hline GEORGIA & 1 \\
\hline GERMANY & 26 \\
\hline GREAT BRITAIN & 5 \\
\hline GREECE & 6 \\
\hline HUNGARY & 30 \\
\hline INDIA & 8 \\
\hline ISRAEL & 2 \\
\hline ITALY & 59 \\
\hline JAPAN & 3 \\
\hline LATVIA & 1 \\
\hline LITHUANIA & 2 \\
\hline MACEDONIA & 2 \\
\hline MEXICO & 4 \\
\hline MOLDOVA & 1 \\
\hline NIGERIA & 1 \\
\hline NORWAY & 1 \\
\hline PERU & 2 \\
\hline POLAND & 24 \\
\hline PORTUGAL & 4 \\
\hline RUSSIA & 125 \\
\hline SLOVAK REPUBLIC & 10 \\
\hline SLOVENIA & 2 \\
\hline SOUTH AFRICA & 1 \\
\hline SPAIN & 33 \\
\hline SWEDEN & 4 \\
\hline SWITZERLAND & 2 \\
\hline THE NETHERLANDS & 2 \\
\hline TURKEY & 3 \\
\hline U.S.A. & 2 \\
\hline UKRAINE & 3 \\
\hline VENEZUELA & 1 \\
\hline ZAMBIA & 1 \\
\hline Total & 514 \\
\hline
\end{tabular}

的には年間 22 ユーロである。2007年度からこれらの 担当が Dr. Hauspie から Dr. Zsakai, A. (Eötvös Loránd Unviversity）に変わり，10月から website の内容も新し くなるとのことであったが，現在のところまだ変更され ていない。改訂が行われば，新しい情報が得られるであ ろう。会員の学問領域は, 日本語に訳すのは難しいので 
欧名のまま示す。Human Evolution, Human Population Genetics, Growth and Development, Applied Anthropology, Paleo-anthropology, Bio-demography, Paleo-Pathology, Human Ecology, Functional Anthropology, Biocultural Researches な どである。

$$
\text { ニュース・レター }
$$

A4 版の 30 ページ位の分量の情報誌で年に $2 \sim 3$ 回送 られてくる。内容の目次は, 例えば, Agenda, EAA News, Congresses, Reports, Announcements, New from the Presses, Contents of Journals, Local Treasurers といったものである。 協議事項, 他の学術大会の開催予定, 新刊本紹介, 新着 関係学術誌の紹介（雑誌名, 著者, タイトル, 刊, 号な ぞ)，学会員の消息などといったところである。

\section{書籍の出版}

Biennial Books of EAA は査読を経た投稿原稿をもとに （依頼原稿もあると思う）二年おきに出版されてきた。こ れまでに次のものが出版された。Vol. 0 (1998) Secular Growth Changes in Europe, Vol. 1 (2000) Human Population Genetics in Europe, Vol. 2 (2002) Ecological Aspects of Past Human Settlers in Europe. Vol. 3 (2004) Physique and Body Composition, Vol. 4 (2006) Human Evolution: Facts and Factors. である。次号は2008 年出版の予定である。

\section{講習会}

EAA 会長の Dr. Susanne, C. (Free University of Brussels) から，大学院生を対象にした初めての試みである講習会 の予報がメールで送られてきた（2006年12月）。タイト ルは Intensive Course In Biological Anthropology Summer
School で, 主催者は The Charles University in Prague と EAA である。会期は 2007 年 7 月 16 日から 30 日までの二 週間。これは学術大会や研究活動ではなく一般的な教育 活動で, 大学院生（修士課程, 博士課程の学生）を対象 にしたもので, 試験も行われ単位が与えられる。その内 容は一般の人類学, 人類進化や人類遺伝に関する授業と 実習で, 教本として, “Essentials of Biological Anthropology” (Charles University Press) が配布される。学生の 選抜は, 講習会参加希望の動機, 履歴書, 指導教官の推 薦状などによって選考される。参加費は 300 ユーロで, 支払いの困難な学生は事前に申し出ると EAA から援助 が期待できる。

\section{ヨーロッパ人類学会学術大会}

Congress of the EAA は二年に一度ヨーロッパで開催さ れる。学会開催地と大会長を表 2 に示す。そもそも筆者 がヨーロッパの学会に出かけたのは, 1988 年東郷正美先 生 (東京大学) に, イギリスでの $5^{\text {th }}$ International Congress of Auxology そその直後 Zagreb で開催される $12^{\text {th }}$ International Congress of Anthropological Ethnological Sciences に参加するよう誘っていただき，おともした時にはじま る。 International Congress of Auxology は基本的には三年 に一度開催される。ちなみに, 初めて参加した 1988 年 はイギリスの Exeter, 順に 1991 年スペインの Madrid, 1994 年ハンガリーの Szombathely, 1997 年アメリカの Philadelphia, 2000 年イタリアの Turin, 2003 年イタリア の Firenze と続き, 今年（2007 年）日本で念願の $11^{\text {th }}$ International Congress of Auxology が芦澤㺵美先生（大妻 女子大学）を会長に田中敏章先生（国立成育医療セン ター）を事務局長として開催された。この Congress には

Table 2 Congress of the European Anthropological Association

\begin{tabular}{llll}
\hline Year & Place & Country & President \\
\hline 1977 & Zagreb & Croatia & Maver, H. and Rudan, P. \\
1980 & Brno & Czech Republic & Jelinek, J. \\
1982 & Petralona & Greece & Poulianos, A. \\
1984 & Florence & Italy & Chiarelli, B. \\
1986 & Lisbonne & Portugal & Castgro e Almeida, M.E. \\
1988 & Budapest & Hungary & Eiben, O.G. \\
1990 & Wroclaw & Poland & Bielicki, T. and Hulanicka, B. \\
1992 & Madrid & Spain & Gerralda, M.-D. \\
1994 & Copenhagen & Denmark & Bennike, P. \\
1996 & Brussels & Belgium & Susanne, C. and Hauspie, R. \\
1998 & Jena & Germany & Jaeger, U. \\
2000 & Cambridge & Great Britain & Mascie-Taylor, C.G.N. \\
2002 & Zagreb & Croatia & Rudan, P. \\
2004 & Komotini & Greece & Xilotiris, N. \\
2006 & Budapest & Hungary & Bodzsar, E.G. \\
\hline
\end{tabular}


第 5 回以降，第 6 回の誌上発表を除き参加することがで きた。このように海外での学会活動はこの Congress を基 軸に予定を立てている。そして，この Congress と同時期 にヨーロッパで開催される興味ある Congress があれば 参加するよう心掛けてきた。2000 年の $9^{\text {th }}$ International Congress of Auxology 直後, $12^{\text {th }}$ Congress of the EAA が Cambridge で開催されたので参加することができた。

\section{$10^{\text {th }}$ Congress of the EAA（Brussels, Belgium)}

初めて Congress of the EAA に参加したのは, 1996年べ ルギーでの Congress で，この時はアメリカのいくつかの 大学と研究所 (Wright State University（旧 Fels Research Institute), University of Arizona, Michigan State University, Michigan University, Ohio State University, National Institute of Health）を服部恒明先生（茨城大学）, 田中茂穂先生 (国立健康栄養研究所) らとともに訪問し, 研究施設の見 学や研究者との意見交換を行った後, 単身 Congress に参 加した。また Congres と同時期に, オランダで Dr. Kemper, H. (Vrije Universiteit van Amsterdam) による Longitudinal Study のセミナーが, Dr. Roche, A. (Write State University), Dr. Malina, R.M.（University of Texas）らを招き開催され ることになっていたが，日程の調整がつかず参加するこ とは断念した。また，筆者はその当時身体組成（Body Composition）の研究に関心があり, 中でも Dr. Clarys, J.P. (Vrije Universiteit Brussel) の研究に興味をもっていたの で，同じ Brussels なので訪問する予定を立てた。予約を 入れて拈いたが, 生憎 Dr. Clarys は出張で不在だった。予 め Dr. Clarys から Dr. Van Roy, P. に研究施設を案内する よう伝えてあったので, Dr. Van Royに案内していただい た。身体組成の研究は, そのほとんぞが非観血的な方法 であるが, Dr. Clarys は解剖学的に, 例えば, 筋重量, 脂 肪重量などを剖出定量していた。そういった研究は我が 国でも汇とんどないので筆者も同じようなことを試みて いたので，ぜひとも実験施設が見たかった。Congressの 会場で Dr. Clarys の研究室にどのように行けばよいのか 尋补た人が大会長の一人である Dr. Susanne で, 懇切丁寧 に教えていただいた。

\section{$15^{\text {th }}$ Congress of the EAA (Budapest, Hungury)}

$15^{\text {th }}$ Congress of the EAA は大会長 Dr. Bodzsar, E.B. (Eötvös Loránd University) のもとハンガリーの Budapest で 2006 年 8 月 30 日から 9 月 3 日まで開催された。筆者は 会場で金澤英作先生（日本大学）と合流した。記憶によ ると, 他には三野 耕先生 (兵庫教育大学), 成山公一先
生 (京都文京大学), 山本和彦先生 (九州大学), 和崎春 日先生（名古屋大学）の大学院生 Ms. Fukushima Byrom Riekoさん, 片山一道先生（京都大学）のトルコからの 大学院生 Ms. Basak Koca Ozerさんらが日本関係の参加者 であった。Plenary Session, Oral Session, Poster Session があ り, Symposium として Human evolution, Human Population Genetics and Biodemography, Growth and DevelopmentDedicated to the memory of O.G. Eiben, Human Ecology, Paleoanthropolgy and Paleopathology, Applied Anthropology などがあった。Growth and Development の Symposium で は, 2004 年末に急逝されたDr. Eibenの名前がタイトルに 添えられていた。

Dr. Eiben, O.G.（Eötvös Loránd University）は1994 年八 ンガリーの Szombathely での $7^{\text {th }}$ International Congress of Auxologyの大会長を務めた。その時初めて会い, 2002 年 の $13^{\text {th }}$ Congress of the EAA (Zagreb)でも勿論会った。2004 年の $10^{\text {th }}$ International Congress of Auxology (Firenze) でも 会らことができた。しかしその年末にDr. Eiben は急逝さ れた。思い起こせば $7^{\text {th }}$ International Congress of Auxology では, Reg Whitehouse Prize の Jury Member を仰せつかっ た。十二名がメンバーであった。その時，韓国から Dr. Beunen, G. (Katholieke University Leuven) のところに留 学していた大学院生 Dr. Son, J.K. がその賞を射止めた。 一票を投じた者としてられしかった。そんなこともあっ てか, それ以来 Dr. Eibenから別刷りが届けられた。学会 終了後, Szombathely から Dr. Danker-Hopfe, H. (Bremen University）とともにドイッに向かった。その途中ウィー ンで Dr. Tanner, J.M. による Tanner-Whitehouse 法のワー クショップに参加した。Dr. Gilli, G. (University of Turin) に前もって連絡を取って彼女とともに参加した。Dr. Tanner は自らX 線写真から骨年齢をコンピューターで 査定する方法を説明された。その様子は日本で見るのと 少し異なり，夫人である Dr. Lindgren との協力関係も微 笑ましかった。その旅行中 Dr. Danker-Hopfeに EAAのこ とを教えていただき入会の誘いを受けた。当時彼女は EAAの会計を担当していた。前後するが，そんなことが あって 1996年の Brussels での Congress of the EAA に初め て参加することになったのである。

話しを $15^{\text {th }}$ Congress of the EAA（2006 年）にもどすと， 筆者はDr. Hauspie の次ぎに発表し, Dr. Eiben に哀悼の意 を捧げることができた。座長は大会長の Dr. Bodzsar と Dr. Cameron, N.（Loughborough University）であった。ま た, 二日目の, Human Ecology-Screening for Health and Disease のセッションでは, Dr. Volanski, N. (Centro de Inves- 
tigacion y de Estudios Avanzados); Dr. Bennike, P. (University of Copenhagen) ; Dr. Schell, L.M. (University at Albany) ; Dr. Mascie-Taylor, N.C.G. (University of Cambridge); Dr. Cameron らが演者で，座長は Dr. Jonston, E.F.（University of Pennsylvania）と Dr. Hauspie であった。なかでも，Dr. Mascie-Taylor $の$ A review of the anthropometric methods of screening for health and disease には, anthropometry の使 い方に工夫があり，新たな魅力ある計測值の使い方を 知った。このように, Congress of the EAA には Congress of Auxologyの多くの常連が参加しており, そのセッショ ンは Congress of Auxologyのようであった。この Congress での発表論文を集めた冊子 Selected Papers of the $15^{\text {th }}$ Congress of the EAA (Bodzsar, E.B. and Zsakai, A. eds. 2007a,b）が出版された。

\section{$13^{\text {th }}$ Congress of the EAA (Zagreb, Croatia)}

$13^{\text {th }}$ Congress of the EAA (2002 年) は $9^{\text {th }}$ International Congress of Physiological Anthropology（Cambridge）の直後に 開催されたので両 Congress に参加した。Cambridge では 多くの生理人類学会の人々と会らことができ,さらにDr. Norgan, N. (Loughborough University) や稲岡司先生（佐 賀大学）にも会った。筆者同様, 両 Congress に参加した 先生方が数名おられた。記憶によると, 門司和彦先生 (長 崎大学), 山本和彦先生 (九州大学), 石橋圭太先生 (九 州大学), 樋口重和先生（国立精神・神経センター）らで ある。Dr. Norgan とは Zagrebの Congress of the EAA でも 一緒だった。その後日本に招聘された時，東大人類生態 学教室（大塚柳太郎先生）主催のセミナーで会った。そ して, Dr. Norgan と山内太郎先生（北海道大学）ととも に茨城大学の服部恒明先生を訪ねた時, Dr. Norgan は部 屋に入るなり壁に貼ってある図を見て開口一番, “Hattori’s Chart”といって身体組成の話題について話し はじめた。今は亡きDr. Norganの姿が思い出される。今 年の夏（2007 年）東京での International Congress of Auxology の後, Society for the study of Human Biology と生 理人類学会の協賛で, A joint meeting between the society for the Study of Human Biology and the Japan Society for the Study of Physiological Anthropology が Cambridge で開催さ れた。東京の International Congress of Auxology に参加し た何人かのゲスト・スピーカもそれに参加した。

筆者は，前述のように Congress of the EAA には 10,12 , 13,15 回大会に参加した。懇親会は，立食，正餐など開 催地によって異なり，海外のマナーに疎い筆者にとって はいい経験になる。そんなことから二年に一度の
Table 3 Honrary members of the European Anthropological Association

\begin{tabular}{lll}
\hline Year & Name & Country \\
\hline 1988 & Jelinek, J. & Czeck Republic \\
1988 & Olivier, G. & France \\
1990 & Ferenback, D. & France \\
1990 & Tanner, J.M. & Great Britain \\
1994 & Prokopec, M. & Czeck Republic \\
1996 & Roberts, D. & Great Britain \\
1996 & Eiben, O.G. & Hungary \\
\hline
\end{tabular}

Congress of the EAA を楽しみにしている。筆者の知る範 囲で, Congress of the EAA に出席する日本人はいつも非 常に少ない。

\section{名誉会員}

名誉会員は表 3 に示す通りである。Jelinek, J.（Czech Republic), Olivier, G. (France), Ferenbach, D. (France), Tanner, J.M. (Great Britain), Prokopec, M. (Czech Republic), Roberts, D. (Great Britain)，Eiben, O.G. (Hungary) が名 を連ねている。筆者が思い浮かべることのできるのは， Dr. Tanner 以降の人々である。それらの人々はHuman Biology 分野の Auxology に関心を持っているからであ る。その中でも特に, Dr. Tannerは日本の Auxology 分野 で著名で，彼の書いた「Growth at adolescence」はその分 野の古典となりつつある。Dr. Robert, Dr. Prockpeck, Dr. Eiben な゙他の名誉会員もAuxology に関心のある人々 で, Congress of the EAA は Human Biologyあるいは Auxology に関心のある者にとっては楽しめる学会だと 思う。AAPA と同時開催の Human Biology Association の Congress にも多くの Auxology に関心のある人々が集ま るように。

\section{最後に}

子どもに関するヒトの生物学の学会はいくつかある。 日本子ども学会, 日本成長学会, 日本発育発達学会など が思い浮かぶ。子ぞもを捉えるには，生物的な側面だけ でなく社会文化的な側面も考慮に入れることが重要であ ることはいらまでもない。そんな思いから，第59 回日本 人類学会大会で, 演者に教育学の今井重孝先生（青山学 院大学), 文化人類学の和崎春日先生 (名古屋大学), 健 康栄養学の田中茂穂先生（国立健康栄養研究所）を招き シンポジウム「子ぞもの発育と身体活動」を行った。そ こでも問題になったのは遺伝と環境の問題である。環境 要因をブラックボックスのように考えることが多く，今 
後環境要因を一つづつ明らかにしていくことが必須であ ると再確認した。今年の $11^{\text {th }}$ International Congress of Auxology での, Dr. Lample, M. (Emory University) の "Life style, growth, health: recognizing the translational biological processes”の講演は聞き応えがあった。1 $5^{\text {th }}$ Congress of the EAA での Dr. Mascie-Tyler の報告も同様，これらは Auxology の今後の研究の展開方向を示す報告であった ように思う。そういった意味で, Dr. Komlos, J. (University of Munich) の Economics and Human Biology が今後どら発 展するのか興味惹かれる。いずれにせよ，楽しい活発な 学会には多くの人が集まるのだろう。

最後に, EAA といえば先ず Dr. Danker-Hopfe との交友 が思い出される。次回の Congress of the EAA は, 2008 年 デンマークの Odense で Dr. Boldsen, J.L. (The University of Southern Denmark）のもとで開催される。

\section{謝 辞}

I am grateful to Prof. Dr. R. Hauspie (Free University Brussels) and Prof. Dr. A. Zsakai (Eötvös Loránd University) for giving me a information about the EAA, and Prof. Dr. H. Danker-Hopfe (University of Bremen, University of Berlin) for recommended me to join the EAA membership and also to attend Congress of the EAA, and for her long term friendship.

\section{参考文献}

Bodzsar, E.B. and Zsakai, A. eds. (2007a) Human Diversity and Biocultural Researches. Selected papers of the $15^{\text {th }}$ Congress of the European Anthropological Association, Human biologia Budapestinesis, 30.

Bodzsar, E.B. and Zsakai, A. eds. (2007b) Growth and Ageing: Facts and Factors. Selected Papers of the $15^{\text {th }}$ Congress of the European Anthropological Association, Human biologia Budapestinesis, 31.

Bodzsar, E.B. and Susanne, C. eds. (2006) Human Evolution: Facts and Factors. Biennial Books of EAA, Vol. 4.

Eötvös Loránd University (2006) $15^{\text {th }}$ Congress of the European Anthropological Association. Man and Environment: Trends and Challenges in Anthropology.

佐竹隆 (2005) フィレンツェ紀行. 美術解剖学雑誌, 9: 33-36.

佐竹隆 (2005) 発育学の課題 (2). 日本大学松戸歯学部教育・ 研究紀要, 7: 22-27.

佐竹隆（2004）特集 家庭と子ども。 子どもと発育発達，2： 巻頭言.

佐竹隆（1997） Prof. Kemper（Vrije Universiteit Amsterdam）と The Amsterdam Growth Study. 体育の科学, 47: 221-224.

佐竹隆 (1996) 海外共同研究についての一考察. 日本大学 松戸歯学部一般教育紀要，22: 155-160.

Tanner J.M. and Lindgren G.W. (1994) The computer-assisted assessment of TW2 Skeletal Age (CASAS). International Satellite Workshop on Bone Age Assessment and Prediction of Adult Height. 